\title{
DNA: prawie niezniszczalny i najbardziej pojemny nośnik danych
}

\author{
Adriana Żyła \\ Uniwersytet im. Adama Mickiewicza w Poznaniu / Adam Mickiewicz University in Poznań (Poland) \\ adrzyl@amu.edu.pl, ORCID 0000-0002-5109-0208
}

\section{STRESZCZENIE}

Dzięki ewolucji technologicznej prawie całkowicie zrezygnowano współcześnie z analogowej archiwizacji informacji (papier, klisza, obraz) na rzecz zapisu cyfrowego. Obecnie potrzeba magazynowania wytwarzanych i przetwarzanych informacji wzrasta w eksponencjalnym tempie. Coraz większą popularnością cieszą się tzw. chmury (cloud) internetowe. Rozwój naukowy podsuwa inne rozwiązanie, zainspirowane najstarszym, ale także niesamowicie trwałym nośnikiem informacji, czyli ciągiem kwasów nukleinowych: DNA. Co więcej, DNA jest bardzo trwałe, a zakonserwowane w odpowiednich warunkach niemal niezniszczalne w odniesieniu do długości ludzkiego życia. Ponadto informacja zawarta w kwasach nukleinowych jest bardzo skondensowana. Oznacza to, że w kilku probówkach możemy zapisać informację o całych serwerach danych. Naukowcy od lat myślą o zastąpieniu cyfrowych nośników danych informacjami zapisanymi w kodzie genetycznym. Dzięki rozwojowi nauki ta perspektywa staje się atrakcyjna.

\section{DNA: an almost indestructible data carrier with incomparable capacity}

\section{ABSTRACT}

Thanks to the technological evolution, analog methods of archiving information (paper, film, image) have been almost entirely replaced by digital storage. Currently, the need for storage of generated and processed information is growing at an exponential rate. The so-called clouds are becoming increasingly popular. Scientific advances suggest yet another solution, inspired by the oldest but also incredibly durable information carrier, i.e. a sequence of nucleic acids: DNA. Moreover, DNA is very durable, and preserved in appropriate conditions, almost indestructible in relation to human lifespan. Further, the information contained in nucleic acids is very condensed. This means that in a scant few test tubes we could store servers' worth of information. Scientists have been thinking for years about replacing digital data carriers with information stored in the genetic code. Thanks to new scientific developments, this prospect is becoming attractive.

\section{SŁOWA KLUCZOWE}

przechowywanie danych, nośniki danych, synteza DNA, magazynowanie danych, wysokoprzepustowe sekwencjonowanie

\section{KEYWORDS}

data preservation, data carrier, DNA synthesis, data storage, high-throughput sequencing 


\section{Wstęp}

Ewolucja technologiczna umożliwiła nam prawie całkowite odejście od analogowej archiwizacji informacji (papier, klisza, obraz) na rzecz zapisu cyfrowego w postaci informacji składającej się z ciągu liczb binarnych (tzw. bitach). Ilość wytwarzanych i przetwarzanych informacji wrasta w eksponencjalnym tempie. Obecnie produkcja nośników danych nie nadąża za tempem produkowanych informacji (Rysunek 1). Istotnym wyzwaniem współczesnej technologii informacyjnej jest również samo przechowywanie danych bez ryzyka ich utraty (naturalny proces „starzenia się” nośników) oraz łatwy i szybki do nich dostęp. Jednym z wyzwań technologicznych jest opracowanie właśnie takich nośników, które sprostałyby tym wymaganiom. Jeszcze do niedawna większość z nas przechowywała pliki bezpośrednio na swoich komputerach, płytach CD lub dyskach zewnętrznych itp., ale obecnie coraz większą popularnością cieszą się tzw. chmury (cloud) internetowe. Oczywiście dane z chmury są przechowywane przez dostawcę na komputerach i dyskach serwera, a to wymaga nie tylko miejsca na dyskach, ale także powoduje znaczne zużycie energii elektrycznej. Rozwój naukowy podsuwa inne rozwiązanie, zainspirowane najstarszym, a także niezwykle trwałym nośnikiem informacji, czyli ciągiem kwasów nukleinowych: DNA.

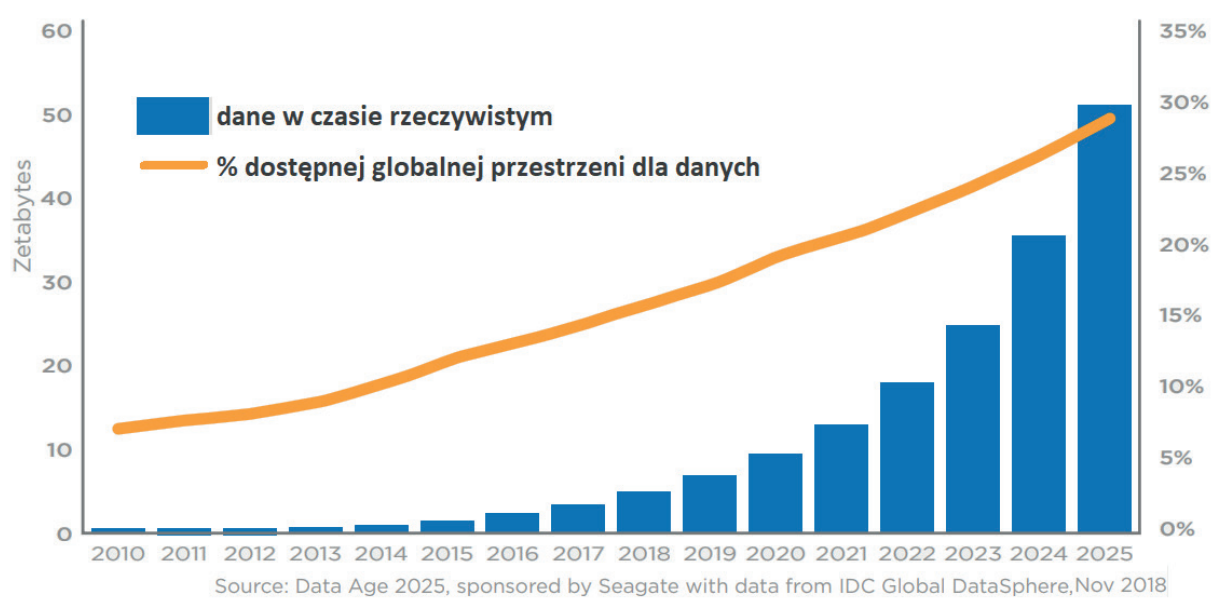

Rysunek 1. Zestawienie roczne globalnej ilości zarchiwizowanych danych i dostępnej przestrzeni do ich przechowywania do roku $2025^{1}$.

1 Źródło: D. Reinsel, J. Gantz, J. Rydning, The Digitization of the World From Edge to Core, Data Age 2025, listopad 2018, https://www.seagate.com/files/www-content/our-story/trends/files/idcseagate-dataage-whitepaper.pdf [dostęp; 16.11.2021]. 
Ogólnie szacuje się, że 1 gram DNA może pomieścić do 215 petabajtów (1 petabajt = 1 milion gigabajtów) informacji² . Co więcej, DNA jest bardzo trwałe (mówimy tu o tysiącach lat ${ }^{3}$ ), a przechowywane w odpowiednich warunkach niemal niezniszczalne w odniesieniu do długości ludzkiego życia. DNA jest więc idealnym nośnikiem danych. Jednak zapis danych na DNA oraz odczytanie danych z DNA na masową skalę w możliwie tani sposób wciąż wymaga dalszych badań.

\section{Historia pomysłu zapisu danych w postaci DNA}

Pierwsza koncepcja o użyciu DNA jako nośnika danych została zaproponowana już w latach 1964-1965, niezależnie od siebie, przez Norberta Wienera i Michaiła Neimana ${ }^{4}$ zaledwie kilka lat od odkrycia struktury DNA.

Pierwsza udana próba zakodowania informacji przy pomocy DNA została dokonana już w 1986 r. przez artystę i badacza z MIT - Joe Davisa5. J. Davis przekształcił germańską runę „ziemi żeńskiej” („Microvenus”) w prosty kod binarny, który z kolei przepisał w sekwencję DNA. Syntetyczny materiał genetyczny wstawiono do żywych komórek Escherichia coli (E. coli).

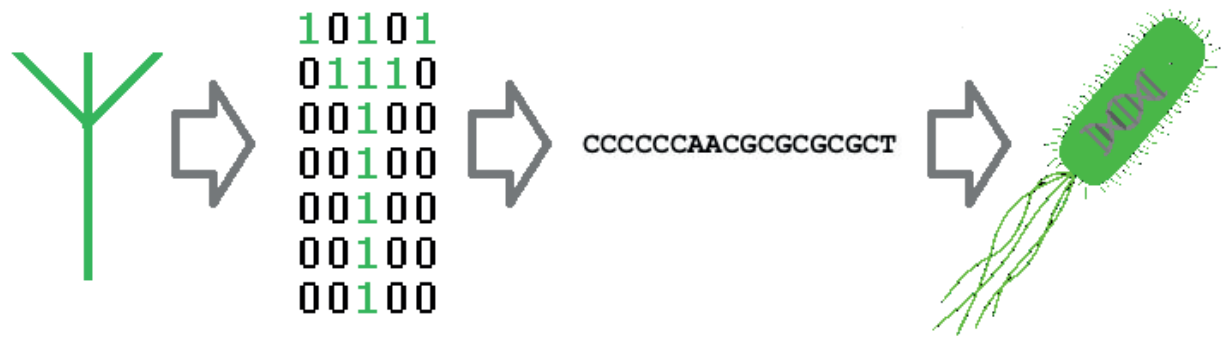

Rysunek 2. Schemat przedstawiający jak ikona Microvenus została zakodowana binarnie, następnie przetłumaczona na DNA, które wstawiono do plazmidu komórek bakterii E.coli. Opracowanie własne.

2 L. Ionkov, B. Settlemyer, DNA: The Ultimate Data-Storage Solution, „American Scientific” 2021, 28 maja, https://www.scientificamerican.com/article/dna-the-ultimate-data-storage-solution [dostęp: 16.11.2021].

3 C. Schwarz, R. Debruyne, M. Kuch et al., New insights from old bones: DNA preservation and degradation in permafrost preserved mammoth remains, „Nucleic Acids Research” 2009, t. 37 (10), s. 3215-3229, DOI:10.1093/nar/gkp159 [dostęp:16.11.2021].

4 Zob. prace M. Neimana: Mikhail Samoilovich Neiman (1905-1975), https://sites.google.com/ site/msneiman1905/eng [dostęp: 16.11.2021].

5 J. Davis, Microvenus, „Art Journal” 1996, t. 55, nr 1, s. 70-74. 
Przełom w opracowaniu praktycznych protokołów do przepisania danych na materiał genetyczny umożliwiły nowe metody do syntezy i sekwencjonowania DNA (czytania DNA), tzw. sekwencjonowanie następnej generacji (Next Generation Sequencing - NGS), które pozwalają na odczyt DNA w wysokoprzepustowej skali w krótszym czasie.

Na początku 2012 r. dwóch naukowców George Church ${ }^{6}$ i Nick Goldman ${ }^{7}$ niezależnie od siebie, powróciło do idei magazynowania danych w DNA. W swoich pracach naukowych G. Church i N. Goldman zaprezentowali, że są w stanie zapisać w DNA informacje o objętości setek kilobajtów. Z kolei Robert Grass zaprojektował protokół przechowania materiału genetycznego w krzemionce. W ramach demonstracji przepisał na DNA album zespołu Massive Attack „Mezzanine” (Rysunek 3).

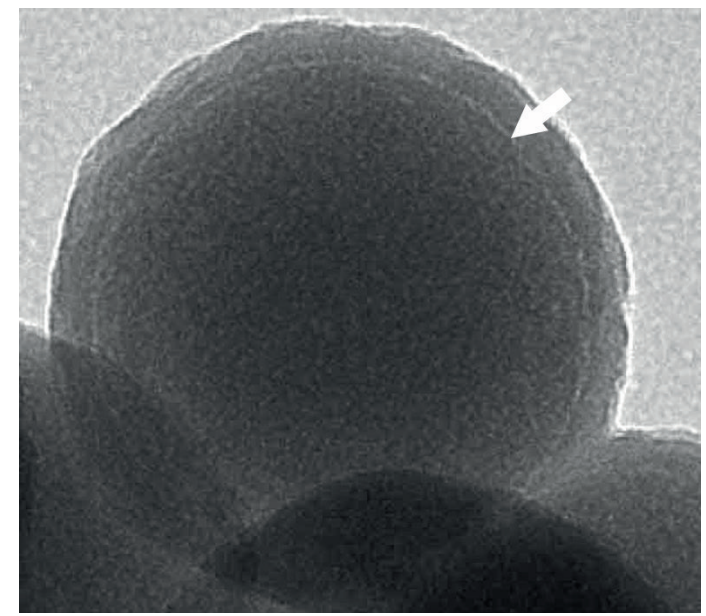

Rysunek 3. Obraz mikroskopowy krzemionkowej kuli o średnicy 160 nanometrów. Cząsteczki DNA, które przechowują informacje dźwiękowe, znajdują się w cienkiej, jasnej warstwie (strzałka). Muzyka całego albumu wymaga 5000 takich kul$^{8}$.

R. Grass oszacował, że DNA zabezpieczone w krzemionce i przechowywane w temperaturze pokojowej (w odniesieniu do Europy Środkowej) nie ulegnie uszkodzeniu przez około 2000 lat. Zaproponował on również algorytmy

6 G.M. Church, Y. Gao, S. Kosuri, Next-generation digital information storage in DNA, „Science” 2012, t. 337, s. 1628-1628.

7 N. Goldman et al., Towards practical, high-capacity, low-maintenance information storage in synthesized DNA, „Nature” 2013, t. 494, s. 77-80.

8 Źrodło: ETH Zurich. Robert Grass, https://control.ee.ethz.ch/people/profile.robert-grass.html [dostęp: 16.11.2021]. 
umożliwiające korekcję błędów, jakie mogłyby się pojawić w wyniku odczytania czy degradacji DNA9 . Obecnie wielu naukowców jest zaangażowanych w prace nad ulepszeniami istniejących metod i protokołów do zapisu i odczytu danych cyfrowych w DNA. W ostatnich latach ukazało się kilka prac opisujących problematykę związaną z praktycznym zastosowaniem tej technologii. W artykule z czasopisma „Nature Protocols”10 opublikowano dokładny protokół na zakodowanie i odkodowanie z powrotem informacji na DNA na przykładzie pliku wideo - odcinka serialu z popularnego serwisu Netflix o tytule „Biohackers”. Co więcej, firma „Catalog” z Bostonu, która kolekcjonuje i przechowuje DNA, ogłosiła, że dzięki opracowanej przez nią technologii do zapisywania/syntezy DNA zakodowała całą anglojęzyczną Wikipedię (Rysunek 4).
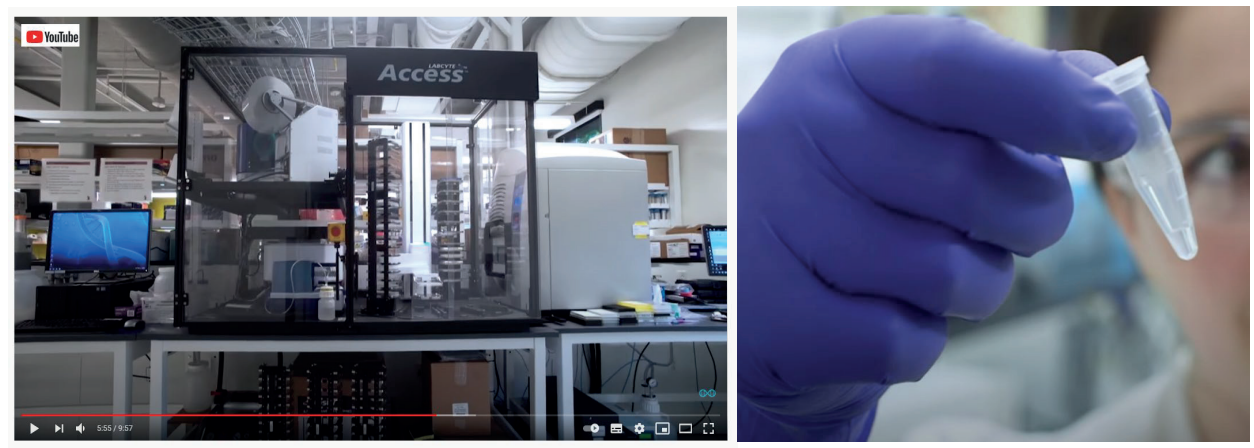

Rysunek 4. Po lewej: maszyna do syntezy DNA zaprojektowana przez firmę Catalog. Po prawej: DNA z Wikipedią ${ }^{11}$.

9 R. Grass et al., Robust chemical preservation of digital information on DNA in silica with error-correcting codes, „Angewandte Chemie. International edition” 2015, t. 54, z. 8, DOI: 10.1002/ anie.201411378 [dostęp: 16.11.2021].

10 L.C. Meiser, P.L. Antkowiak, J. Koch et al., Reading and writing digital data in DNA, „Nature Protocols" 2019, t. 15, s. 81-101, DOI: 10.1038/s41596-019-0244-5 [dostęp: 16.11.2021].

11 Źródło: YouTube. Introduction to DNA-based data storage and CATALOG, https://www. youtube.com/watch?v=IiPvJfbq2No [dostęp: 16.11.2021]. 
Tabela 1. Zestawienie opublikowanych przez naukowców zapisanych i zachowanych danych in vitro $w \mathrm{DNA}^{12}$

\begin{tabular}{|c|c|c|}
\hline Opublikowane & Rozmiar zakodowanych danych & $\begin{array}{c}\text { Długość fragmentów } \\
\text { nici DNA }\end{array}$ \\
\hline Church et al. (2012) & $650 \mathrm{kB}$ & 115 \\
\hline Goldman et al. (2013) & $630 \mathrm{kB}$ & 117 \\
\hline Grass et al. (2015) & $80 \mathrm{kB}$ & 158 \\
\hline Bornholt et al. (2016) & $150 \mathrm{kB}$ & 117 \\
\hline Erlich et al. (2017) & $2 \mathrm{MB}$ & 152 \\
\hline Blawat et al. (2016) & $22 \mathrm{MB}$ & 230 \\
\hline Organick et al. (2018) & $200 \mathrm{MB}$ & $150-200$ \\
\hline Anavy et al. (2018) & $8.5 \mathrm{MB}$ & 194 \\
\hline Choi et al. (2018) & $854 \mathrm{~B}$ & 85 \\
\hline Yadzi et al. (2018) & $3 \mathrm{kB}$ & $880-1000$ \\
\hline Organick et al. (2018) & $33 \mathrm{kB}$ & 150 \\
\hline Lee et al. (2018) & $18 \mathrm{~B}$ & $150-200$ \\
\hline Meiser et al. (2019) & $553 \mathrm{MB}$ & 151 \\
\hline Koch et al. (2020) & $1.4 \mathrm{MB}$ & 104 \\
\hline
\end{tabular}

\section{Jak zakodować informacje w DNA - konwersja pliku do sekwencji DNA}

W pracy opublikowanej w „Nature Protocols”13 naukowcy zaproponowali szczegółowy protokół na zakodowanie informacji w materiale genetycznym. Protokół ten został wstępnie zoptymalizowany na rozmiar danych od $100 \mathrm{kB}$ do 15 MB. Cała procedura składa się z pięciu etapów, gdzie krok pierwszy skupia się na przeniesieniu pliku na bity danych, a następnie na sekwencje DNA. Ponieważ metody syntezy DNA mają swoje ograniczenia i maksymalna (bez wprowadzenia możliwości błędów) długość syntezowanego pojedynczego fragmentu DNA to

12 Tabela została zaczerpnięta z L. Ceze, J. Nivala, K. Strauss, Molecular digital data storage using DNA, „Nature Reviews Genetics” 2019, t. 20, s. 456-466, DOI: 10.1038/s41576-019-0125-3 [dostęp: 16.11.2021] oraz uzupełniona o publikacje z ostatnich lat.

13 L.C. Meiser, P.L. Antkowiak, J. Koch et al., op. cit. 
170-300 nukleotydów, wydajność zależy od techniki i konkretnego producenta (Custom Array, Twist Bioscience, Agilent Technologies). Ponadto pula fragmentów DNA jest magazynowana w próbce jako mikstura wszystkich fragmentów DNA. Oznacza to, że sekwencjonowane fragmenty będą odczytywane w sposób losowy. Przy tym odczytane fragmenty sekwencji mogą wykazywać wysoki stopień podobieństwa. Niezwykle istotnym elementem projektowania algorytmów do przepisania bitów danych na sekwencje DNA jest oznaczenie każdego fragmentu danych tak, aby po jego odczytaniu móc odtworzyć oryginalną kolejność zapisanych danych.

Typowy łańcuch DNA składa się z nukleotydów, czterech podstawowych zasad azotowych: dwóch purynowych - adenina (A) i guanina $(G)$ - oraz dwóch pirymidynowych - cytozyna (C) i tymina (T). Do konwersji plików binarnych na sekwencje DNA użyto następującej zależności: dla bitów 00 przypisano A, dla 01 - C, dla 10 - G i dla 11 - T. Ten sposób konwersji umożliwia zapisanie dwóch bitów cyfrowej informacji na nukleotyd.

\section{Syntetyczne DNA}

Obecnie na rynku istnieje kilka firm, które zajmują się syntezą zamówionych sekwencji DNA na szeroką skalę. Rozwój nowych metod syntezy, a w szczególności wysokoprzepustowe technologie syntezy i łączenia genów (ang. high-throughput gene synthesis and assembly) stają się siłą napędową biologii syntetycznej i są kluczowe do opracowania skutecznej metody przechowywania danych w DNA.

Zastosowanie DNA jako nośnika danych wciąż wymaga postępów w przepustowości syntezy i redukcji kosztów w przeliczeniu na nukleotyd. Dzięki rozwojowi nowych technologii cena produkcji zadanego ciągu nukleotydów jest coraz niższa, a na przestrzeni ostatnich lat obserwujemy znaczny spadek kosztów syntezy DNA (Rysunek 5). W ostatnim dziesięcioleciu koszt syntezy metodą kolumnową (column-based), przeliczony na jeden nukleotyd, to od 0.05 USD do 0.15 USD $^{14}$. Niedawno firma Catalog ${ }^{15}$ ogłosiła, że jest w stanie przepisać na DNA

14 S. Li-Fu, D. Zeng-Hua, G. Zi.-Yi, L. Lu-Lu, L. Bing-Zhi, Large-Scale de novo Oligonucleotide Synthesis for Whole-Genome Synthesis and Data Storage: Challenges and Opportunities, „Frontiers in Bioengineering and Biotechnology" 2021, t. 9, DOI: 10.3389/fbioe.2021.689797 [dostęp: 16.11.20201]. Przykładowy cennik usługi syntezy DNA zob.: Bio Basic. Pricing and Turnaround, www.biobasic.com/genes-pricing/ [dostęp: 16.11.2021].

15 Zob. strona internetowa firmy Catalog: Catalog. In the news, https://www.catalogdna.com/ press [dostęp: 16.11.2021]. 
około 1 Megabita danych na dzień. To jednak wciąż niewystarczająco, jeżeli chcielibyśmy zastosować DNA przy obecnym zapotrzebowaniu na magazynowanie danych cyfrowych.

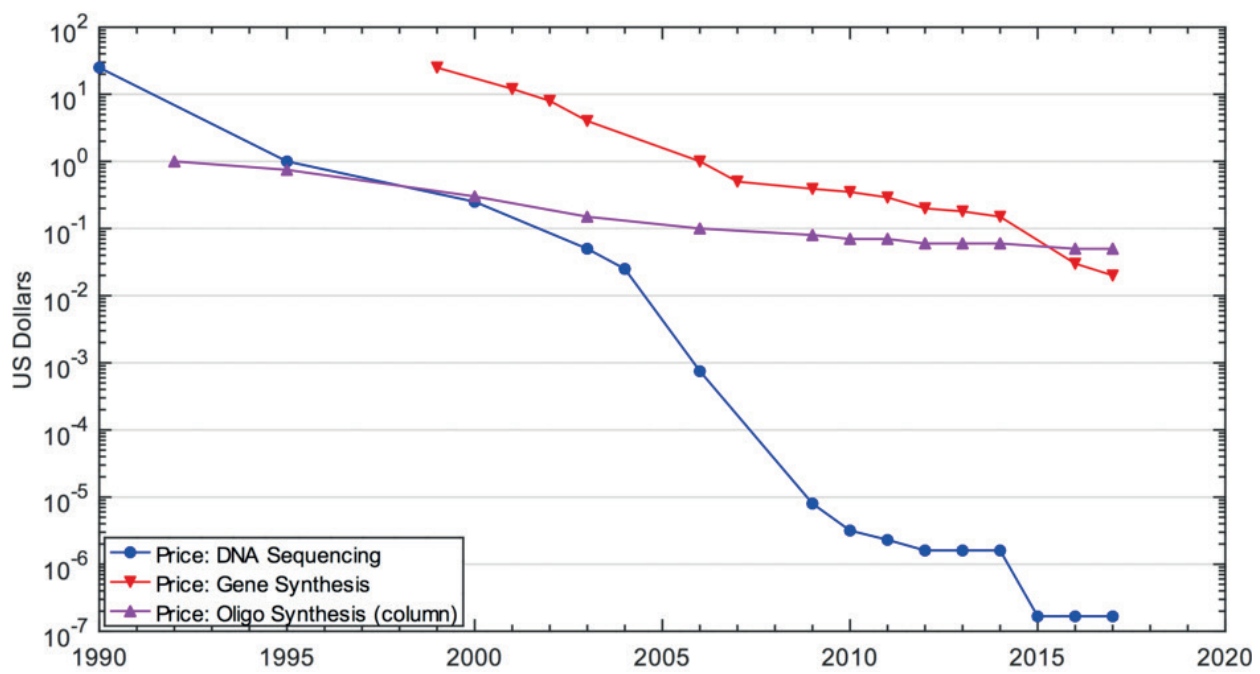

Rysunek 5. Cena syntezy (w USD) i sekwencjonowania przeliczona na jedną resztę DNA (circa 2017 r. $)^{16}$.

\section{Przechowywanie DNA}

DNA jest cząsteczką o niezwykle trwałej naturze. Wykazuje wysoką odporność chemiczną, m.in. na ciepło czy utlenianie. Przykładem zachowania informacji genetycznej przez setki, a nawet i tysiące lat są starożytne skamieliny. Dodatkowo niska temperatura (zamrożenie), zamknięcie w krzemionce ${ }^{17}$ lub po prostu wysuszenie DNA (dehydratacja) i przechowywanie w izolacji zwiększa odporność materiału genetycznego na degradację. Jedną ze zdecydowanych zalet DNA jest to, że zawiera ono informacje niezwykle skondensowane, co oznacza, że w małej objętości możemy zakodować bardzo dużą ilość danych, czyli w kilku probówkach

16 Źródło: Synthesis Rob Carlson. On DNA and Transistors, www.synthesis.cc/synthesis/ category/Carlson+Curves [dostęp: 16.11.2021]; R. Carlson, The changing economics of DNA synthesis, „Nature Biotechnology” 2009, t. 27, s. 1091-1094, DOI: 10.1038/nbt1209-1091 [dostęp: 16.11.2021].

17 D. Paunescu, R. Fuhrer, R. Grass, Protection and deprotection of DNA - high-temperature stability of nucleic acid barcodes for polymer labeling, „Angewandte Chemie” 2013, t. 52, s. 4269-4272, DOI 10.1002/anie.201208135 [dostęp: 16.11.2021]. 
możemy mieć informacje o całych serwerach danych. Co więcej, te dane można przechowywać w zamrażarce przez tysiąclecia, a ponieważ materiał genetyczny jest niezwykle trwały, można go bez problemów transportować.

\section{Odczytywanie DNA - sekwencjonowanie}

Sekwencjonowanie DNA, podobnie jak w przypadku syntezy DNA, jest coraz tańsze, a metody coraz dokładniejsze (Rysunek 5). Jedną z najbardziej rozpowszechnionych wysokoprzepustowych technologii do sekwencjonowania jest platforma Illumina z serią sprzętu NextSeq. Najnowsze instrumenty NextSeq umożliwiają odczytanie około 1000 GB sekwencji danych w niecałe dwa dni. Metody Illuminy wykazują się również bardzo niskim współczynnikiem błędu. Bezbłędne sekwencjonowanie jest kluczowym parametrem dla późniejszego zdekodowania pliku z DNA na plik binarny.

\section{Dekodowanie DNA na plik binarny}

Ostatnim elementem, który należy wziąć pod uwagę, jest ponowna konwersja sekwencji DNA na plik binarny. Ponieważ w każdym kroku mogą pojawić się błędy, niezbędne jest zastosowanie rozwiązań, które umożliwią zabezpieczenie przed potencjalną utratą danych. $\mathrm{W}$ opublikowanym niedawno protokole ${ }^{18}$ badacze zaproponowali zabezpieczenie przed potencjalnym wprowadzeniem błędów do danych, a mianowicie wprowadzili redundancję danych przed przeniesieniem ich na daną sekwencję. Dzięki zwiększonej redundancji po sekwencjonowaniu przechowywanego materiału genetycznego możliwe jest zastosowanie algorytmów umożliwiających korekcję błędów np. za pomocą tzw. algorytmu Reeda-Solomona (kody szeroko stosowane w korekcji błędów przy zapisie na płytach CD, DVD, Blu-ray, w kodach QR, technologiach transmisji danych itd.).

Konwersja sekwencji DNA do pliku binarnego jest możliwa za pomocą programu operującego na pliku tekstowym z sekwencjonowania i, w zależności od parametrów komputera jak i wielkości pliku, może być wykonana w stosunkowo szybkim czasie.

18 L.C. Meiser, P.L. Antkowiak, J. Koch et al., op.cit. 


\section{Magazynowanie danych cyfrowych w DNA}

Rozwój nauki i coraz to nowych i, co najważniejsze, tańszych i szybszych metod do syntezy i sekwencjonowania DNA sprawia, że jesteśmy coraz bliżej rozwiązania problemu przechowywania olbrzymiej ilości danych cyfrowych. Co prawda obecne metody nie są na tyle wieloprzepustowe, aby szybko zapisać i odczytać dane, ale prawdopodobnie za kilka lat zamiast w olbrzymich energochłonnych komputerach serwerowych będziemy przechowywać dane w zamrażarce. Samo zakonserwowanie ważnych danych w kodzie genetycznym daje nam zabezpieczenie, że nie utracimy cennej wiedzy czy informacji. Chociaż na całym świecie wiele naukowych i prywatnych organizacji pracuje nad rozwojem tych technologii, na ich praktyczne zastosowanie musimy jeszcze poczekać.

\section{Bibliografia}

Bio Basic. Pricing and Turnaround, www.biobasic.com/genes-pricing/ [dostęp: 16.11.2021].

Carlson R., The changing economics of DNA synthesis, „Nature Biotechnology” 2009, t. 27, s. 10911094, DOI: 10.1038/nbt1209-1091 [dostęp: 16.11.2021].

Catalog. In the news, https://www.catalogdna.com/press [dostęp: 16.11.2021].

Ceze L., Nivala J., Strauss K., Molecular digital data storage using DNA, „Nature Reviews Genetics” 2019, t. 20, s. 456-466, DOI: 10.1038/s41576-019-0125-3 [dostęp: 16.11.2021].

Church G.M., Gao Y., Kosuri S., Next-generation digital information storage in DNA, „Science” 2012, t. 337, s. $1628-1628$.

Davis J., Microvenus, „Art Journal” 1996, t. 55, nr 1, s. 70-74.

ETH Zurich. Robert Grass, https://control.ee.ethz.ch/people/profile.robert-grass.html [dostęp: 16.11.2021].

Goldman N. et al., Towards practical, high-capacity, low-maintenance information storage in synthesized DNA, „Nature” 2013, t. 494, s. 77-80.

Grass R. et al., Robust chemical preservation of digital information on DNA in silica with errorcorrecting codes, „Angewandte Chemie. International edition” 2015, t. 54, z. 8, DOI: 10.1002/ anie.201411378 [dostęp: 16.11.2021].

Ionkov L., Settlemyer B., DNA: The Ultimate Data-Storage Solution, „American Scientific” 2021, https://www.scientificamerican.com/article/dna-the-ultimate-data-storage-solution [dostęp: 16.11.2021].

Li-Fu S., Zeng-Hua D., Zi.-Yi G., Lu-Lu L., Bing-Zhi L., Large-Scale de novo Oligonucleotide Synthesis for Whole-Genome Synthesis and Data Storage: Challenges and Opportunities, „Frontiers in 
Bioengineering and Biotechnology" 2021, t. 9, DOI: 10.3389/fbioe.2021.689797 [dostęp: 16.11.2021].

Meiser L.C., Antkowiak P.L., Koch J. et al., Reading and writing digital data in DNA, „Nature Protocols” 2019, t. 15, s. 81-101, DOI: 10.1038/s41596-019-0244-5 [dostęp: 16.11.2021].

Mikhail Samoilovich Neiman (1905-1975), https://sites.google.com/site/msneiman1905/eng [dostęp: 16.11.2021].

NextSeq ${ }^{\circledR} 500$ System WGS Solution, www.illumina.com/documents/products/appnotes/appnotenextseq-500-wgs.pdf [dostęp: 16.11.2021].

Paunescu D., Fuhrer R., Grass R., Protection and deprotection of DNA - high-temperature stability of nucleic acid barcodes for polymer labeling, „Angewandte Chemie” 2013, t. 52, z. 15, s. 4269-4272, DOI 10.1002/anie.201208135 [dostęp: 16.11.2021].

Reinsel D., Ganta J., Rydning J., The Digitization of the World. From Edge to Core, Data Age 2025, listopad 2018, https://www.seagate.com/files/www-content/our-story/trends/files/idc-seagate-dataage-whitepaper.pdf [dostęp; 16.11.2021].

Schwarz C., Debruyne R., Kuch M. et al., New insights from old bones: DNA preservation and degradation in permafrost preserved mammoth remains, „Nucleic Acids Research” 2009, t. 37 (10), s. 3215-3229, DOI:10.1093/nar/gkp159 [dostęp; 16.11.2021].

Synthesis Rob Carlson. On DNA and Transistors, www.synthesis.cc/synthesis/category/ Carlson+Curves [dostęp: 16.11.2021].

YouTube. Introduction to DNA-based data storage and CATALOG, https://www.youtube.com/ watch?v=IiPvJfbq2No [dostęp: 16.11.2021]. 